\title{
Basin Management in a Mature Closed Basin: The Case of California's Central Valley
}

\author{
Mark Svendsen \\ Consultant in Water Resources Management \\ Philomath, Oregon, USA
}

\begin{abstract}
The American State of California is a mature water economy in which available water is nearly fully allocated. The state has a well-developed hydraulic system which enables water to be moved from areas of surplus to deficit, and allows trading and sales of water and water rights, though such transactions are still limited. The state is overwhelmingly urban and still growing rapidly, leading to large projected increases in municipal water demands over the next 20 years. Additional allocations to municipalities are expected to come from allocations currently devoted to agriculture.
\end{abstract}

Procedures for managing water at the basin level have solid, if complex, underpinnings in law and tradition. Surface water rights are based on both riparian and appropriative doctrines. However, groundwater is only lightly regulated and is currently seriously overdrafted. Management is pluralistic, with multiple sources of power and authority. Many decisions are negotiated, rather than handed down, and then formalised as legally-enforceable agreements among the involved parties. Others are litigated, and reliance on the courts for dispute resolution is heavy.

The various interests, including the natural environment, are represented by capable and well-funded advocates. Decisions are generally considered in open fora with the full range of interests represented. Many of the actors involved have come to realise that past reliance on litigation to resolve disputes does not necessarily lead to optimal solutions, and there is a broad interest and willingness to experiment with alternative models of decision-making and dispute resolution.

\section{Introduction}

\subsection{Basin management}

River basins are managed at two different levels. At the higher level, the basin level, overall policies and plans are set, resources are allocated and regulations written and enforced. At the use level, regulated water deliveries are made to users of water, who may be irrigators, urban residents, industries, wetlands, or natural river reaches. This paper focuses on the first level of management, the basin level, and examines the way in which basin level management functions are performed in the large interior Central Valley of California. The Central Valley comprises what Bandaragoda (c1999) terms an advanced river basin, one which is already well developed in terms of physical infrastructure and effective institutions for integrated water resource management. 
Issues of particular interest here are the interplay of political forces which support alternative water uses, the currently changing priorities accorded to alternative water uses, and processes and institutions whereby allocational and regulatory activities at the basin level are directed and co-ordinated. One central issue of global significance is the extent to which one apex organisation must be in control of the highest level of decision-making in a basin. Berkof (1997), for example, has asserted that "if water is to be managed holistically, all aspects must be coordinated by one ... agency." The present study suggests that this assertion does not apply universally and raises questions about the conditions under which different models of basin-level management would be most effective.

\subsection{California's Central Valley}

California's Central Valley is home to millions and one of the premier agricultural regions in the United States, containing 6 of the top 10 agricultural counties in the country. California itself has $\mathbf{3 3}$ million residents and is the most populous state in the nation. An overwhelming 97 percent of the population live in urban areas.

The state as a whole has abundant renewable water resources which, in addition to meeting environmental, urban, and agricultural needs, generate 42 percent of the utility-produced electricity in the state. Irrigated agriculture generates 81 percent of California's total agricultural revenue on 30 percent of the state's farmland. Agricultural also provides 14.4 percent of the state's employment, though only 2.1 percent of that is engaged in direct production activities. The remaining 12.3 percent works in input production, marketing and processing, and wholesale and retail sales. The state is also blessed with a magnificent and varied natural environment-the Pacific coast, the Sierra Nevada Mountains, broad inland valleys, wetlands, and the southern deserts. All of these features-the environment, urban concentrations, power generation, and agriculture-require water for their sustenance and operation.

Several features of California's situation make it especially valuable as a case for study.

- Firstly, California comprises a sophisticated economic environment in which water is used for a wide variety of purposes and is treated more as a commodity than as a common pool resource.

- Secondly, intense competition over water has emerged in what Seckler (1996) would call a closed water system - one in which there is little new water left to develop. This competition includes agricultural, municipal and industrial (M\&I), and environmental interests and is driving rapid change in the institutions which allocate, regulate, convey, and use water.

- Thirdly, the responses to changing public priorities have been characterised by pragmatic problem-solving behaviour. This has made California a virtual laboratory for innovative solutions to problems of water reallocation and management, environmental quality, efficient water use, and water quality management. 


\section{Basin hydrology 1}

\subsection{Supply}

California possesses abundant water resources, receiving nearly 250 billion ${ }^{2} \mathrm{~m}^{3}$ of precipitation annually in average years. Of this amount about 65 percent is used by trees and other natural vegetation. An additional 10 percent flows to the Pacific Ocean or other salt sinks unchecked and unallocated. The remaining 25 percent runoff is available as a renewable water supply for urban, agricultural, and environmental uses ${ }^{3}$.

Developed surface water resources in the state total about 80 billion $\mathrm{m}^{3}$, of which nearly half are set aside as required environmental flows ${ }^{4}$. About 12 percent of the total has been developed under Federal Government projects, 5 percent by the State of California, and 17 percent by local government entities. An additional 8 percent comprises water imported from the Colorado River basin under a multistate water-sharing agreement using facilities also constructed by the Federal Government.

In addition to surface water sources, an additional 15 billion $\mathrm{m}^{3}$ is available as renewable groundwater (see footnote 5). Present withdrawal rates are higher than this, resulting in an overdraft of about 1.8 billion $\mathrm{m}^{3}$ annually, some 12 percent of the renewable total. Furthermore, the rate of overdraft is increasing and was 10 percent greater in 1995 than it was in 1990. To some extent, this overdrafting is a consequence of 1992 federal legislation which reallocated water away from irrigators to environmental uses. This has led to supply deficiencies of up to 50 percent for some Central Valley irrigators and caused them to turn to lightly regulated groundwater as a replacement supply.

Most of California's precipitation falls as snow in the mountains of northern California and in the Sierra Nevada range, which comprises the high backbone of the state running from north to south along its eastern flank (Figure 1). A second range of much smaller hills, the Coastal Range, fronts the narrow coastal plain in the west, creating a broad alluvial valley between the two ranges. This Central Valley is an area of rich soils and favourable growing conditions for a wide variety of crops and is the heart of California agriculture. In it, more than 200 types of crops are grown and from it comes 45 percent of the nation's fruits and vegetables. Two major river systems drain the Central Valley and some $158,000 \mathrm{~km}^{2}$ of watershed, the Sacramento River in the north, and the San Joaquin River in the south. The two

'Data for this section is drawn largely from DWR (1998).

${ }^{2}$ Billion is defined here as $10^{9}$.

${ }^{3} \mathrm{~A}$ portion of the water specifically designated for in-stream environmental use also flows to the Pacific Ocean.

${ }^{4}$ The total of developed surface and groundwater is greater than the 25 percent of precipitation designated as available runoff because of reuse. 
Figure 1. California's Central Valley

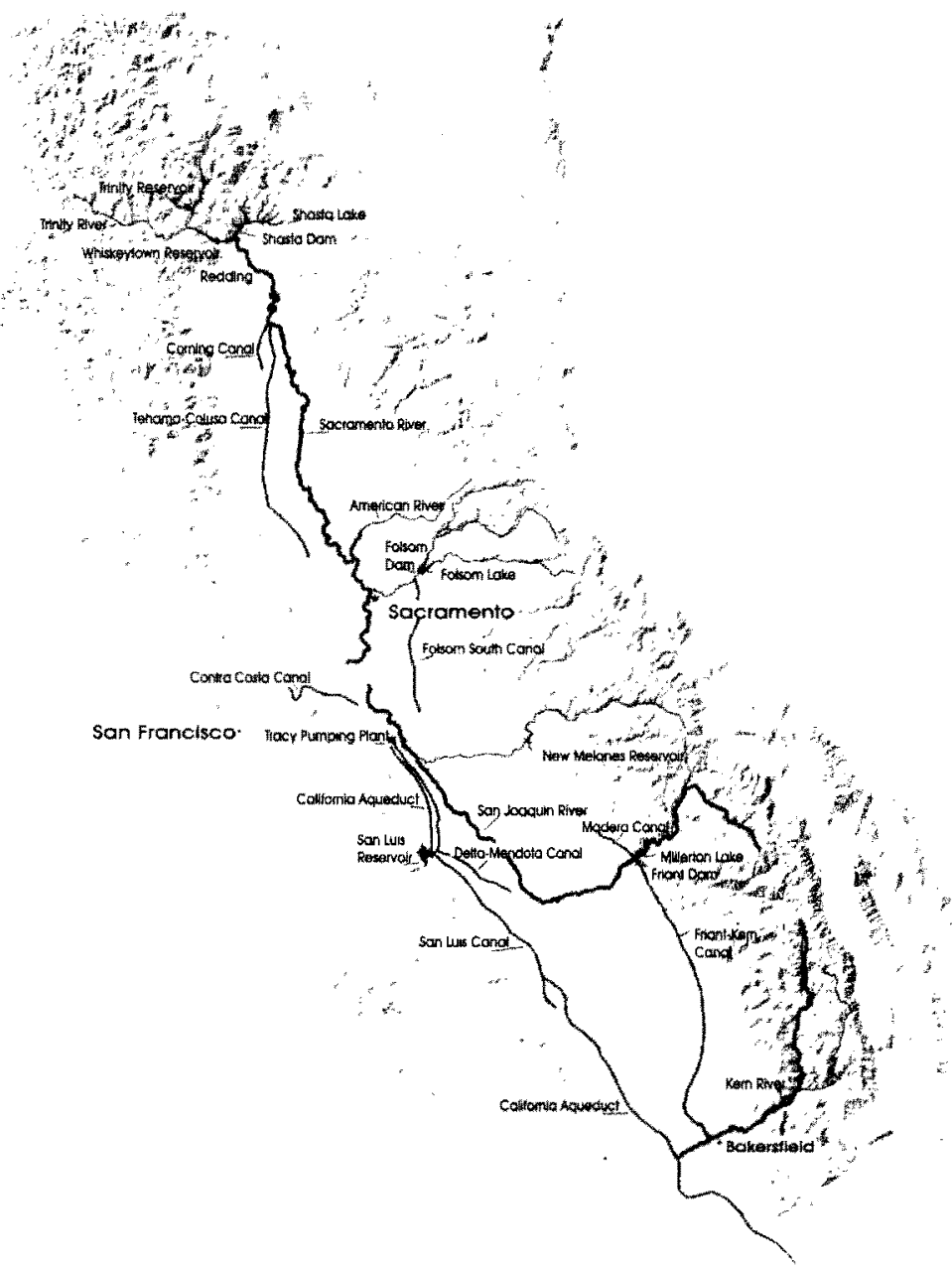


rivers meet in the Sacramento-San Joaquin Delta (the Delta), just inland of San Francisco Bay, from where they flow into the Bay and out to the Pacific Ocean.

The fact that two-thirds of California's water is in the north, while the bulk of agricultural land and the largest population centres are in the south has led to two massive engineering projects designed to transport water from north to south. These are the federal Central Valley Project (CVP) and the State Water Project (SWP).

The CVP was constructed in the 1940s by the Bureau of Reclamation, the federal irrigation development agency. Construction was begun in 1935 as a part of a massive depression-era public works programme. The project is anchored by Shasta dam in the Cascade Mountains in northern California which stores water for use in the south. Water from Shasta and several smaller dams is routed down the Sacramento River to the Delta, which it crosses in a network of natural and artificial channels. Some of the water is used to irrigate land along the Sacramento River to the north, but most crosses the Delta to be lifted 60 meters into the Delta-Mendota Canal (DMC). The DMC supplies 32 irrigation districts in the San Joaquin Valley with water.

The second project, the SWP, was developed in the 1960s by the State of California. Its backbone, the California Aqueduct, parallels the DMC south from the Delta before continuing on to southern California. Its primary purpose is to Convey M\&I water to desert cities in the south $(70 \%)$, principally the greater Los Angeles area, though it does supply irrigation water $(30 \%)$ as well. Together these two projects deliver about 7.3 billion $\mathrm{m}^{3}$ of water annually to the south.

\subsection{Demand}

\subsubsection{Current patterns}

Overall demand for developed sources of water is dominated by environmental reservations $(46.5 \%)$ and by irrigated agriculture $(42.5 \%)($ Table 1$)$. Municipal demand currently makes up 11.0 percent of the total.

Table 1: Average water-year water uses, 1995 and 2020

\begin{tabular}{|l|c|c|c|c|}
\hline \multirow{2}{*}{} & \multicolumn{2}{|c|}{1995} & \multicolumn{2}{c|}{2020} \\
\cline { 2 - 5 } & $\begin{array}{c}\text { Volume } \\
\left(10^{4} \mathrm{~m}^{3}\right)\end{array}$ & $\begin{array}{c}\text { Share } \\
(\%)\end{array}$ & $\begin{array}{c}\text { Volume } \\
\left(10^{\circ} \mathrm{m}^{3}\right)\end{array}$ & $\begin{array}{c}\text { Share } \\
(\%)\end{array}$ \\
\hline Urban & 10.8 & 11.0 & 14.8 & 14.9 \\
\hline Agricultural & 41.7 & 42.5 & 38.9 & 39.1 \\
\hline Environmental & 45.6 & 46.5 & 45.6 & 45.9 \\
\hline Total & 98.0 & 100.0 & 99.3 & 100.0 \\
\hline
\end{tabular}




\subsubsection{Changing patterns of demand}

Projections for 2020 (DWR, 1998) anticipate only a very modest expansion in available supply $(1 \%)$, but with important shifts in the composition of use. While environmental uses of water are expected to remain constant, urban ${ }^{5}$ demand will expand by 37 percent and agricultural water use will shrink by nearly 7 percent to accommodate this growth. Additional developed supplies will be devoted entirely to urban use.

The federal Endangered Species Act, passed in 1973, established the legal framework for protecting species of plants and animals listed as threatened or endangered and the allocation of water for their preservation where necessary. The listing of winter run Sacramento River salmon as endangered under this act in the early 1990 s was the first important application of the law in California that had a significant impact of water allocation in the Sacramento-San Joaquin Valley. A far more sweeping change was wrought by the Central Valley Improvement Act, passed by Congress in 1992. This act reallocated a portion of the water, which the federal government had contracted to deliver to irrigation districts, to the ecosystems of the Sacramento-San Joaquin Delta. This reallocation has resulted in significant shortfalls in supplies to many of the irrigation districts in the San Joaquin Valley.

\subsubsection{Urban use}

Driving the growth in urban water use is projected growth in the California population of nearly 50 percent between 1995 and 2020 , as a result of continuing in-migration from others regions of the country and from abroad. The demand for water caused by this growth completely overshadows modest potential reductions in per capita water use of about 6 percent if household level best management practices are fully implemented ${ }^{\circ}$.

\subsubsection{Agricultural use}

California has more than 3.6 million hectares of agricultural land under irrigation, 80 percent of it in the Central Valley. Projections for 2020 indicate a modest reduction of about 130,000 hectares $(3.6 \%)$ in the total irrigated area, resulting mainly from urban encroachment, land retirement due to drainage problems, and more competitive economic markets for agricultural products ${ }^{7}$. In addition, changes in cropping patterns and irrigation technology and practices will yield small reductions in the rate of water use per hectare (an estimated $2.4 \%$ of 1995 use levels).

\footnotetext{
'Urban use includes residential, commercial, industrial, and institutional uses of water

${ }^{6}$ If explicit conservation practices are not implemented, per capita urban demand will increase by about 6 percent.

There is potential for much more significant reductions if major proposed conversions of agricultural land to wildlife habitat are implemented.
} 


\subsubsection{Environmental use}

Environmental water use comprises several categories of flows that have been set aside for environmental purposes. These are:

- Dedicated flows in designated "wild and scenic" rivers (64\%)

- In-stream flow requirements in other rivers established by water right permits, court actions, agreements, or other regulatory actions (17\%)

- Required Sacramento-San Joaquin Deita outflows (15\%)

- Wetlands freshwater requirements $(4 \%)$

Note that while there are other environmental uses of water, the above uses are distinguished by being managed and quantifiable. Most of this environmental water allocation is brought about by legislative and regulatory processes rather than through the water right permitting process which authorises agricultural and municipal uses.

\subsection{Summary}

California is well endowed with renewable water resources. Of the 250 billion $\mathrm{m}^{3}$ received as precipitation annually, about one-quarter is available for various allocated uses. About half of this allocated water is set aside for instream environmental uses. The remainder (just over 50 billion $\mathrm{m}^{3}$ ) is available for withdrawal for agricultural and urban uses. Groundwater, though abundant, is currently overdrafted by about 12 percent of the renewable total and exploitation continues to expand.

Two major plumbing projects, one Federal and the other State, transfer water from the wet north to the arid south of the state. Water moving though both of these systerns must transit the Sacramento-San Joaquin Delta "in the open", where it mixes with water in the Delta and contributes to it. The Delta is also important environmentally, and it serves as the nexus of the debate over the future of California water.

According to the most recent version of the California Water Plan, urban demand, is expected to grow by 37 percent over the next quarter-century; while agricultural water use shrinks by 7 percent and environmental use holds constant. Additional allocations to environmental uses are being promoted, however, and if they are adopted additional reallocation of agricultural water will be the likely outcome. 


\section{Legal, policy, and institutional environment}

\subsection{Water rights}

Water in California, as in the United States in general, is regarded as a good belonging to all and held in trust by the State ${ }^{8}$. Management of water, and allocation of rights to use water, are responsibilities of the individual states. Rights to use water in California comprise a complicated mixture of types, priorities, and levels of security. Groundwater and surface water rights are treated separately, and surface water rights, which are the most important, include both riparian and appropriative rights. Underlying and articulating the various elements of the allocation scheme are a number of state and federal laws and numerous court cases, each of which establishes precedents upon which subsequent cases build.

Riparian rights to surface streams are available, under common law, to the owners of property abutting streams. Water abstracted under a riparian right cannot be applied to plots of land which do not abut the stream and cannot be transferred to other uses removed from the riparian land. They comprise about 14 percent of rights to non-imported surface water in California.

Appropriative rights to surface water are more flexible and comprise the remaining 86 percent of non-imported surface water rights. Appropriative rights are granted through a permitting process managed by the State of California. Appropriative rights can be for use at points removed from the stream of origin and are subject to transfer and change of purpose. Maintenance of an appropriative water right requires continuous beneficial use, and the courts have held that appropriative rights can be lost after five years of non-use. Riparian rights are neither created by use nor lost by non-use.

Groundwater use is only lightly regulated. There is no permitting process for groundwater exploitation, which is available, in the first instance, to owners of overlying land for reasonable beneficial use on those lands. Groundwater users establish rights simply by use. Rights are correlative with the rights of other owners, meaning that if the water supply is insufficient, the supply must be equitably apportioned. Subject to future requirements on overlying lands, "surplus" groundwater may be appropriated for use on non-overlying lands. Again, no permit is required.

This very vague and permissive specification of rights to groundwater has two important implications. Firstly, as pressure on nearly fully allocated surface water sources continues to build, users turn to groundwater to make up deficits, leading to a serious and growing problem of overdrafting in many portions of the state. Secondly, groundwater is a magnet for litigation as water users joust over such terms as "surplus", "sufficient", "reasonable", "equitable" and "beneficial." Development of a suitable institutional framework for managing groundwater in the state is urgently needed but proceeding slowly.

${ }^{8}$ This is the Public Trust Doctrine, derived from Roman Law. 


\subsection{Actors}

There are seven important groups of actors involved in basin-level water management in California, in addition to the general public. These are the mangers, the service providers, the users, the regulators, advocacy groups, elected officials, and the courts. Some groups, such as regulators, service providers, the courts, and elected officials, consist of both federal and state level actors, while others are purely local. The main actors in each category are discussed briefly below.

\subsubsection{Managers}

The most important managing organisations are two California state organisations-the Department of Water Resources (DWR) and the State Water Resources Control Board (SWRCB). The DWR replaced the Office of the State Engineer in 1956, assuming responsibility for planning and guiding development of the state's water resources. Over the past 45 years it has grown from 450 staff to a level ten times that in 1967 before dropping back, and now employs about 2,000 . DWR operates on an annual budget of about $\$ 1$ billion and is a division of the state public administration under a director who is accountable to the state governor. Its responsibilities are primarily technical and operational, but do include some regulatory functions. Major responsibilities include the following:

- $\quad$ Preparing and updating the California Water Plan every five years

- Operating and maintaining the State Water Project

- Protecting and restoring the Sacramento-San Joaquin Delta

- Dam regulation and flood protection

- Public education

- Providing technical assistance to local communities

The SWRCB performs functions which are managerial, regulatory, and quasijudicial in nature. It thus occupies a special niche in the overall set-up. Among its important responsibilities are the following:

- Allocating rights to appropriate (use) surface water

- Adjudicating disputes over rights to water bodies, such as the Sacramento-San Joaquin Delta

- Establishing water quality standards

- Guiding and overseeing the nine Regional Water Quality Control Boards

Board appointments are made by the governor and the make up of the Board is as described in the box on the following page. 
Regional Water Boards under the SWRCB do not allocate water rights but manage and regulate water quality through the following kinds of action:

- Writing waste discharge permits

- Implementing contamination clean up operations

- Monitoring quality and use of regional groundwater and surface water

- Inspecting discharges and enforcing state and federal water quality laws

Regional Boards consist of five members who are also appointed by the governor.

\subsubsection{Service providers}

At the basin level, the most important water service providers are the United States Bureau of Reclamation (USBR or "the Bureau") and DWR. The USBR is an agency of the Federal Government housed in the Department of the Interior. The Bureau constructed most of the federally-financed water conveyance and control facilities in the state, including the pivotal Central Valley Project (CVP), and operates the storage and delivery facilities it has constructed. However, while it retains operating responsibility for the upstream portions of the CVP, it has recently transferred operating responsibilities for the portions of the system lying south of the Delta to an association established and controlled by San Joaquin Valley water users, the San Luis-Delta Mendota Water Authority (SLDMWA). Users have proposed that they assume responsibility for the upstream portions as well, but action on that step is more controversial.

The other major water storage and conveyance project in the state, the State Water Project (SWP), is operated by DWR, which constructed the facilities using state resources.

\subsubsection{Users}

Principal water users are the various districts which purchase water and deliver it to the members or residents in the district. Districts are generally organised to supply irrigation water to farmers or municipal water to urban residents. Districts are incorporated as non-profit entities under state law and are selfgoverning. The largest share of managed surface water is delivered to agricultural users, most of whom are in the Central Valley. Other users include the state Department of Fish and Game, conservation districts, hydropower facility operators, and DWR and the USBR for flood control operations. Freshwater navigation, though significant in the past, is of minor importance today. 


\section{Evolution of a Water Control Agency}

1940 s Serious water-quality problems emerged in California, including outbreaks of water-borne diseases and degradation of fishing and recreational waters. In 1949 a fact-finding committee highlighted cumbersome and unreasonable laws and administrative procedures, multiple jurisdictions, limited and conflicting interests, and overlapping authorities as roots of the evident problems. The committee concluded that the state's limited water resources could only be extended through planning to maintain water quality while at the same time allowing maximum economic use and reuse. It recommended a central focus point at the state level to co-ordinate water pollution control activities.

1949 Legislation created a State Water Pollution Control Board consisting of nine gubernatorial appointees representing specific interests and four ex officio state officials. Its duties included formulating state-wide policy for pollution control and co-ordinating the actions of various state agencies and political subdivisions of the state in controlling water pollution. The same legislation created nine Regional Water Pollution Control Boards in major watersheds. These regional boards had responsibility for administration, investigation, and enforcement of the state's pollution abatement programme. Five gubernatorial appointees, representing water supply, irrigated agriculture, industry, and municipal and county government in the region, served on each regional board.

1959 The 1949 law was revised and broadened on the basis of 10 years of experience. State ex officio members were removed from the board, increasing its separation from the state administrative machinery.

1963 The state board was renamed the State Water Quality Control Board and given the broader mandate of water quality control, replacing the more limited earlier focus on sewage and industrial waste control.

1967 A proposal to consolidate water-related functions, including water quality control functions, within the Department of Water Resources was rejected on the grounds that this would create conflicts of interest internal to DWR. Instead quantity and quality management functions were consolidated external to DWR by merging the State Water Quality Control Board and the State Water Rights Board into the State Water Resources Control Board. The "State Water Board" consists of five full-time members mandated to protect water quality and to determine rights to surface water use. Members are appointed by the governor and fill specialised roles on the Board, e.g. attorney versed in water law, two civil engineers with expertise in water rights and water supply, a water quality member, and a public member.

1969 A new Water Quality Control Act was passed which retained the basic structure of state and regional boards but provided a new regulatory framework for waste discharges to both surface water and groundwater. This act served as a model for the federal Clean Water Act, passed three years later.

Source: http:/wwwdwr.water.ca.gov 


\subsubsection{Regulators}

Water-related regulation centres around provisions of federal and state laws, protecting endangered species and maintaining drinking water quality. The federal Endangered Species Act of 1973 is the most important of these and is enforced by the national Environmental Protection Agency (EPA). Of the endangered species affecting water use in California, the most critical are the listed runs of salmon. Technical regulations and certifications relating to salmon are made by the National Marine Fisheries Service (NMFS) while criteria for other animal species are set and supervised by the federal Fish and Wildlife Service.

State environmental regulators also list endangered species, and this list includes some which are not on the federal list. The state Fish and Game Department supervises enforcement of water quality and quantity requirements relating to state-listed species.

The State Water Resources Control Board and its subtended regional boards bear overall responsibility for surface water and groundwater quality in the state. The Federal Clean Water Act and the California Water Quality Control Act, both aimed at pollution control, are enforced by these boards.

\subsubsection{Advocates}

One of the most dramatic recent changes in the cast of characters in the water drama in California, and in the United States, is the emergence of environmental advocacy groups as potent political actors. Most groups are membership-based and supported and often draw on grants from charitable foundations. Some focus on a single issue-a resource or species-while others have a broader range of interests. The group Friends of the River is an example of a resource-focussed group which is largely concerned with restoring free-flowing rivers in California, while the Sierra Club, based in California but national in scope, is an example of a group with a wide range of conservation interests beyond water. There are about 20 environmental groups in California interested in water issues. These groups are linked through an Environmental Water Caucus which meets every couple of weeks. Accompanying expanded federal and state environmental regulation over the past 25 years has been greatly strengthened requirements for transparency in regulatory processes.

\subsubsection{Elected officials}

Legislators at both the Federal and State levels write the laws providing the framework for water resource management in the state. Although establishing systems for allocating water resources is in the purview of the state legislature, the federal government exerts a powerful influence on water allocation by applying the terms of the federal Endangered Species Act. This act constrains waterrelated construction projects in various ways, and can require increased in-stream allocations of water for fish species classed as threatened or endangered. The governor is a particularly important figure in the state water resource management picture, controlling appointments to the State Water Board and the regional Water 
Quality Boards and as the head of the state administrative apparatus which includes the important DWR. The US Congress also influences allocation through its ability to mandate changes in water permits which are held on behalf of the US Government by the US Bureau of Reclamation. Water quality is regulated by both federal and state statutes.

\subsubsection{Courts}

Both State and Federal courts hear cases relating to water. Where the US Government is a party to the litigation, a Federal court must be the venue, as State courts cannot have jurisdiction over the Federal Government. Almost all of the cases heard are civil cases rather than criminal cases, involving disputes between parties rather than violations of state or federal law.

A Federal judge in the Central Valiey indicated that about 20 percent of his caseload consisted of water cases, and that the volume of water-related cases had increased considerably over the past nine years. Cases have also increased in complexity. The introduction of the Federal ESA and the listing of a number of fish species in important California rivers have played a major role in this increased complexity. The integration of Public Trust Doctrine into California water law ${ }^{9}$ has also made decisions more complicated. Throughout this period of change, the NGO sector has increasingly become a "third presence" in nearly every significant civil case, seeking to include the environmentalist viewpoint into the deliberation.

Major drawbacks to the heavy reliance on the court system for dispute resolution are the often drawn-out nature of proceedings, their expense, and the difficulty of reaching sound decisions through adversarial proceedings. A Federal Judge interviewed cited approvingly an old adage, "hard cases make bad law." Increasingly attention is shifting to various modes of alternative dispute resolution.

\subsection{Essential functions}

Burton (1999) has identified 11 essential functions of basin management. A somewhat modified listing of these functions is shown in Table 2, crossed with the key actors identified in the previous section. These functions are replicated, as appropriate, across four broad categories - surface water, groundwater, wastewater disposal, and agricultural return flows. Cells are marked to indicate an actor which is active in a particular functional area. Information is drawn from interviews, printed materials and Internet postings. A number of interesting points emerge from an examination of Table 2.

${ }^{9}$ Accomplished by a decision of the state supreme court in 1983 in a suit filed by the National Audubon Society. 


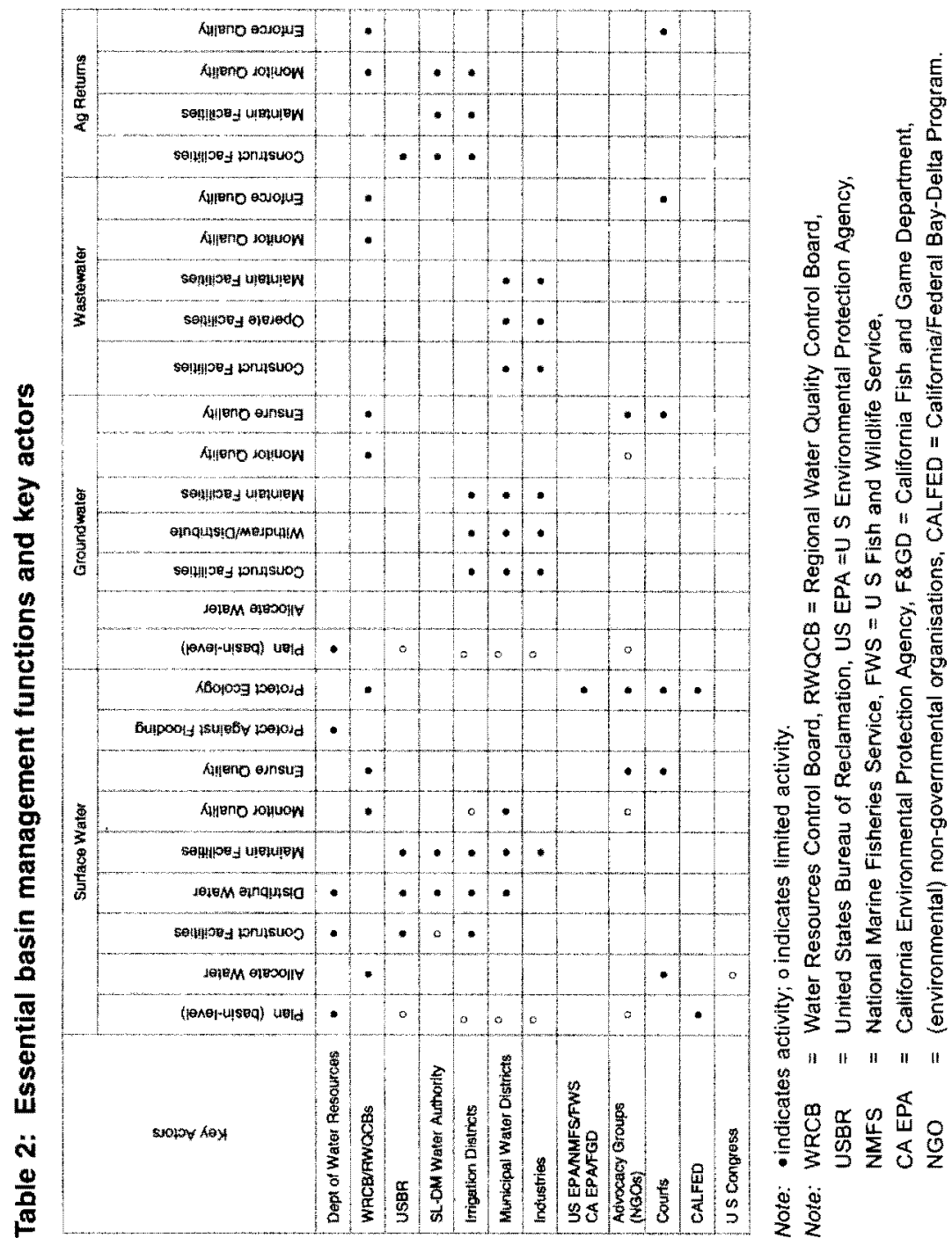


- A comprehensive planning function rests with the state Department of Water Resources. This responsibility covers surface water and groundwater in both quantity and quality. Although technical analyses and modelling are done by DWR, extensive interaction with a variety of stakeholders in the planning process makes planning a widely shared activity. The primary planning document is the State Water Plan, which is updated in a process led by DWR every five years.

- Surface water allocation and water quality assurance are assigned to a single state agency, which is independent of the other state agencies engaged in planning or system operations. The WRCB is autonomous, though it is political to the extent that the members are appointed by the governor of the state. The U.S. congress assumed a certain amount of de facto allocational authority in passing a 1992 law which directed the USBR to reallocate water from agricultural users with whom it held contracts to environmental uses. Federal and state courts also play important roles in the allocational process by resolving disputes over allocation.

- Enforcement of water quality standards rests with nine regional boards with strong local ties but under the overall guidance of the state-level WRCB. The courts also play significant roles in interpreting disputes related to water quality.

- Retail water delivery services are, for the most part, in the hands of user-controlled districts. Such irrigation and municipal water supply districts are financially autonomous and self-regulating. They usually obtain water from wholesale suppliers through legally-enforceable contracts.

Groundwater is the most lightly-planned and regulated segment of the state's water resources. There is little control over abstractions and the state is in a serious overdraft situation.

Advocacy groups (environmental NGOs) make up an important third presence in most important disputes involving water. This is a relatively recent development but has profoundly changed the way in which decisions are made, and modified their outcomes. These groups also play important roles in joint consensual processes, such as CALFED and the American River Water Forum, which are being used increasingly to develop mutually acceptable plans and agreements over contentious water-related issues.

- There is a certain conflict within the DWR regarding its dual roles as wholesale supplier of water, water resource planner, and regulator. Transparency of process appears to keep these potential conflicts in check. Although not included in the table there is a significant conflict of interests internal to the U S Army Corps of Engineers, which is charged with wetland permitting and protection, but is primarily a construction and operating agency with close ties to the congressional appropriations process. 


\subsection{Co-ordinating processes}

Managing an important publicly-held natural resource will always involve multiple actors, differing interests and perspectives, and relational dynamics. This is true even in situations where a single agency is responsible for all aspects of basin water management, as there will be winners and losers among users of basin water resources and factions within the managing agency having differing perspectives and interests.

In California, where there are many discrete actors in the water resource allocation and management picture, co-ordination and decision-making have long been critically important functions. Traditionally, the courts, both federal and state, have provided a critical dispute resolution function. As the Sacramento-San Joaquin basin has closed and water become relatively more scarce, disputes have become more frequent and the number of interested parties has grown, making proceedings more complex. There is presently growing interest in various forms of Alternative Dispute Resolution, including the use of mediation, arbitration, and special masters.

There is also growing reliance on processes of shared consensual decisionmaking to replace the more typical twostage process of a technical decision made by a government agency, followed by extensive and lengthy litigation initiated by unsatisfied parties. The most prominent example is the ongoing CALFED process, which tackles some of the most contentious water-related problems in the

\section{Bay-Delta Problem Areas \\ - Ecosystem restoration \\ - Water quality assurance \\ - Levee system improvement \\ - Water supply reliability} state, as shown in the box at right.

CALFED is a consortium of federal and state government agencies with management and regulatory responsibilities in the Bay-Delta system. It was formed in 1994 with the mission of developing a long-term comprehensive plan that will restore ecological health and improve water management for beneficial uses of the Bay-Delta system, the heart of the Central Valley hydraulic system. CALFED spent its first two years identifying and defining problems and a further four years assessing the environmental implications of various actions which might be taken. It is about to begin an implementation phase that could last 30 years and cost $\$ 10$ billion.

What sets CALFED apart from other programmes is the fact that problems and solutions are being discussed from the outset in an open forum with participation that spans the entire range of water-related interests, and that it is proposing an entire basket of measures which will address the four problem areas in an integrated, complementary, sustainable way. Fundamental principles guiding the process are shown in a second box. Striking is the commitment of all participating parties to make the CALFED approach work. This commitment arises in part from the fear that if the process fails, years of litigation will follow in a far more adversarial process of dispute resolution. 


\begin{tabular}{|c|c|c|}
\hline \multicolumn{3}{|c|}{ CALFED Solution Principles } \\
\hline Affordable & - & $\begin{array}{l}\text { solution can be implemented and maintained } \\
\text { with the foreseeable resources of the CALFED } \\
\text { stakeholders }\end{array}$ \\
\hline Equitable & - & $\begin{array}{l}\text { solution will focus on resolving problems in all } \\
\text { problem areas }\end{array}$ \\
\hline Implementable & - & $\begin{array}{l}\text { solution have broad public acceptance, legal } \\
\text { feasibility and will be timely and relatively } \\
\text { simple compared with alternatives }\end{array}$ \\
\hline Durable & - & $\begin{array}{l}\text { solution will have political and economic staying } \\
\text { power }\end{array}$ \\
\hline Reduce conflicts & - & $\begin{array}{l}\text { solution will reduce major conflicts among } \\
\text { beneficial users of water }\end{array}$ \\
\hline No redirected impacts & - & $\begin{array}{l}\text { solution will not solve Bay-Delta problems by } \\
\text { exporting them elsewhere }\end{array}$ \\
\hline
\end{tabular}

\subsection{Enabling conditions}

The essential functions and actors' roles depicted in Table 2 provide a static view of responsibilities. Additional attributes of well-functioning basin governance ${ }^{10}$ systems relate to their dynamics. We term these attributes which provide the context for functional performance enabling conditions.

Enabling conditions are features of the institutional environment at the basin level that must be present, in some measure, to achieve good governance and management of the basin. These attributes are not specific to any one actor, but apply to all actors and their interactions and comprise necessary (but not sufficient) normative conditions for success. Basic enabling conditions are shown in the box at right. While a full analysis of these factors is well beyond the scope of this paper, a brief sketch of each, in the context of California, is given to illustrate the concepts and indicate broad strengths and weaknesses.

\footnotetext{
${ }^{10}$ The term governance is used is a somewhat different sense here than in Burton's list of essential attributes, of which it is one. Here the term refers to the rules providing the context for multi-actor basin management and the processes and activities engaged in by those actors operating within this set of rules.
} 


\subsubsection{Political attributes}

Representation is generally well developed, with groups having similar interests allied into various associations. These associations are supported by the members with funds for representation and litigation. Environmental concerns are represented by NGOs which have grown over the past 25 years in number, resources, and influence. Supported by protections provided by federal and state endangered species laws, they now enjoy power commensurate with the other major players.

\begin{tabular}{|c|}
\hline Enabling Conditions \\
Political Attributes \\
Representation of interests \\
Balanced power \\
Informational Attributes \\
Process transparency \\
Information availability \\
Information accessibility \\
Legal Authority \\
Appropriate institutions \\
Adequate powers \\
Resources \\
Human \\
Financial \\
Institutional \\
Infrastructural
\end{tabular}

\subsubsection{Informational attributes}

The availability of information and transparency of decision-making processes in the United States, and in California, has also expanded over the past quartercentury. These changes have been driven by requirements in environmental protection laws, by the existence of the world-wide web, and by growing public demand for information and openness. It is now a rare decision-making process that is not characterised by ready availability of technical information, public hearings, and extensive opportunities for public comment.

\subsubsection{Legal authority}

The system of water rights, though complex, is relatively well specified in law and through cumulative court decisions. Rights to surface waters are more clearly spelled out than those to groundwater, and the latter area is one where a stronger and more appropriate legal basis is required. There is a sound legal framework underlying user-based districts which provide such services as irrigation, domestic water supply, groundwater management, and wetland conservation. Districts are self-financing and self-governing and generally work effectively.

\subsubsection{Resources}

Though participants always feel that financial resources are inadequate, both financing and human resources within the basin management system appear generally adequate. There is a well developed physical infrastructure for transferring water around the state, and from neighbouring basins, and a steady stream of additions and improvements to it. Environmental restrictions and concerns, however, make infrastructural design a far more demanding process than it previously was, and have stymied completely some proposed projects, such as the peripheral canal around the delta. New institutional forms (along with a legal basis for them) will likely be required in the future to legitimise and implement consensual agreements reached by ad hoc bodies such as CALFED, but the need for these is still evolving. 


\section{Salient characteristics of California basin management}

A number of important features characterise basin water management in California. These are summarised below.

- Multiple sources of authority and power. No single public agency manages water resources in California's river basins. Instead, decisions are made and enforced by a number of state and federal agencies. Integration is provided by the State Water Plan, various regional plans and processes such as CALFED, the centralised system of surface water rights, and the court system.

- Dynamic interplay of competing interests. An even broader group of actors participate in and influence decision-making. These actors are from both public and private sectors. They debate in a variety of fora to assert their points of view. These include public hearings, the media, and the courts. Extensive lobbying of public officials also takes place behind the scenes. Decisions emerge from this interplay.

- Adequate representation of all interested parties. Major parties in the water debate are well represented and financed. These include municipal water districts, agricultural water districts, public water supply agencies, state and federal environmental regulators, and environmental NGOs.

- Heavy reliance on legally-enforceable contracts and agreements. Many of the water-related decisions made take the form of contracts or agreements between two or more parties, rather than administrative decrees. This requires confidence on all sides in the enforceability of the agreements.

- Separation of operating and regulatory functions. Regulatory functions are generally handled by organisations which are independent of federal, state, and user-controlled operating agencies.

- Adequate databases on hydrologic processes and capacity to research new issues. Extensive measurement and data collection programmes have created a large database of information on California water resources and their uses and impacts. Equally importantly, a strong technical capacity exists in the private sector to conduct additional assessments, on a consulting basis, as needs arise.

- Open access to information and generally transparent decisionmaking processes. Information on water flows, water quality, wastewater quality, water rights, and so on is avallable to the public and is generally accessible through the world wide web and in publications and public records. Decision-making processes are 
generally conducted in the open and include public hearings ${ }^{11}$. Moreover decisions reached are accessible to challenge in court and decisions over controversial issues often are so challenged.

- Self-financing autonomous districts as retail service providers. Retail water service delivery is typically handled by Irrigation or water districts, which are user-controlled, self-financing, non-profit quasimunicipal entities incorporated under state law. This vastly simplifies the service delivery problem by reducing the number of major "users" to several hundred from tens of thousands.

- Important role of an impartial court system in resolving disputes. Federal and state courts are regularly called upon to settle disputes brought to them as civil suits. Without this service, the water resource maniagement system in the state would be unworkable.

- Well-defined system of water rights (except groundwater). There is a clear system of allocating and protecting rights to surface water which provides reasonable security to users. Protection of groundwater is presently more problematic.

\section{Bibliography}

Bandaragoda, T. c1999. Case studies of advanced river basins: best practices of river basin management.Colombo, Sri Lanka: International Water Management Institute. Unpublished note.

Berkoff, J. 1997. Water resources functional analysis. Report prepared for the Sri Lanka Water Resources Council. Colombo.

Burton, M. 1999. Note on proposed framework and activities. Prepared for the IWMI/DSI/CEVMER Research Programme on Institutional Support Systems for Sustainable Management of Irrigation in Water-Short Basins. Izmir.

Department of Water Resources, 1998. California Water Plan Update Bulletin 160-98. Department of Water Resources, Sacramento.

Seckler, D. 1996. The new era of water resources management: from "dry" to "wet" water savings. IIMI Research Report 1. Colombo, Sri Lanka: International Irrigation Management Institute.

\footnotetext{
"As is always the case, real compromises are often hammered out in private by a smaller group of participants. Nevertheless, the compromises reached must be capable of standing up to public and interest group scrutiny when they are announced.
} 